\title{
Evaluation on The Process of Development of Agricultural Modernization In 2013 of China
}

\author{
Quan Dai ${ }^{1, a}$, Huilan Ma ${ }^{1, b}$ and Yang $S u^{1, c}$ \\ ${ }^{1}$ College of Economics and trade, Xinjiang Agricultural University, Xinjiang Urumuqi \\ City,China,830052 \\ a28864899@qq.com, bmhl2020@sina.cn, c 398199494@qq.com
}

Keywords: Agricultural modernization; Indicator system; Evaluation; China

\begin{abstract}
This article use the agricultural modernization development level evaluation model, using data of the China statistical yearbook and China rural statistical yearbook, to evaluate the level of the china agricultural modernization in 2013, and compared with the results of 2008, proposed that China agricultural modernization development process change significantly, the level of development stage has leap in 15 provinces and regions.
\end{abstract}

\section{Introduction}

The evaluation and analysis of the development level of China's agricultural modernization is conductive to discover timely new trends and new problem in the process of development of agricultural modernization. In this paper, the author calculated the development level of agricultural modernization of various provinces in 2013 and compared with the results of 2008, as well as explored the changes in the process of national agricultural modernization.

\section{Selection of Evaluation Index System of Agricultural Modernization}

Characteristics and problems of main evaluation methods at present. In recent years, many domestic scientific research institutions and scholars have carried abundant research on the development of agricultural modernization. Because of the wide range of agricultural modernization, the current researches generally build a comprehensive index system, to reflect the development level of agricultural modernization scientifically and rationally.

In the selection of index, although due to the differences in geographical boundaries or first grade index classification, there are differences in the number of specific index, the selection of core index is relatively close. For example, Jiang Heping, Cui Qifeng (2009) proposed index system including ten indices of four major categories, that is interrelated integration, production conditions, production effects, ecological environment. Zhang Shuying, Xia Xinmin and other people (2012) proposed that index system includes eighteen indices of six major categories, that is agricultural output benefits, agricultural facilities, agricultural science and technology progress, agricultural industry management, agricultural ecological environment, agricultural support guarantee. There are five same indices in these two indices systems, they are farmers per capita net income, agricultural science and technology contribution ratio, the level of agricultural comprehensive mechanization, land output ratio, the ratio of agricultural products processing output and agricultural output. In view of the complex problems of the index system of agricultural modernization development level, Chen Qi, Hu Zijun (2012) simplified the 12 indices of four major categories proposed by Xin ling, Jiang Heping (2010) into nine indices, proved that the results of the improved index system are same as that of the original results.

Expert score and AHP methods are usually used in the determination of index weight, such as Jiang Heping, Cui Qifeng (2009) and other scholars. However, some scholars, such as Shen Qi, Hu Zijun (2012) adopt factor analysis to determine the weight. 
In the method of single index scoring, ratio method to compare the actual value and the target value, so as to realize the standardization of index system. Such as Jiang Heping, Huang Delin (2005) and other people.

When comparing the index system, the common problem is that the same index name has different content. For example, Zhuang Shuying, Xia Xinling (2012) clearly defined land output rate as the added value of agriculture animal husbandry and fisheries in the unit of agricultural land in his index system. While the index system proposed by Jiang Heping and Cui Qifeng (2009) defined the land output rate as the gross output value of the unit cultivated land area. The difference of these two is that the agricultural land area includes cultivated land, forest land, garden cultivation surface, meanwhile, the added value of agriculture animal husbandry and fisheries is generally greater than that of agricultural production. The same problem also appears in the difference of rural population, rural workers and rural worker in primary industry in the statistical yearbook when the population acts as an indicator.

Selection of evaluation index system. This paper adopts the comprehensive index system evaluation method proposed by Xin Ling and Jiang Heping (2010), so as to facilitate the comparison of national and provincial of agricultural modernization development level in 2013 and 2008.The index system includes twelve indices of four major categories, that is agricultural input level, agricultural output level, rural social development level and agricultural sustainable development level.(Specific indices and weights are shown in Table 1).

$$
\text { Basic evaluation model: } A_{t}=\sum_{i=1}^{n} C_{i} B_{i}
$$

Among EQ.1, $A_{t}$ stands for the comprehensive index score of agricultural modernization development level at phase $t . B_{i}$ is index, $C_{i}$ stands for the weight of this class index.

According to the international practice and China's agricultural development, the development stages of agricultural modernization can be divided into three stages. Among them, we call it the initial stage if the scores $A_{t}$ is lower than 40 , the development stage if the scores of $A_{t}$ is greater than 40 and less than 80 , the mature stage if the scores of $A_{T}$ is greater than 80.

Definition and illustration of indices. The priority is to define some indices that need indirect calculation prior to the use of the model, in order to ensure the comparability of the results.

The education level of agricultural labor force refers to the proportion of the rural labor force whose education level is junior high school in rural labor force, it is sample data; the total power of the unit cultivated land refers to the ratio of the agricultural machinery to cultivated area; the per capita GDP is the ratio of the added value of agriculture to the total population of the country; labor productivity is the ratio of the added value of agriculture to the number of workers in primary industry; the land productivity is the ratio of the added value of agriculture to cultivated land; the employment rate of the agricultural labor force is the ratio of employed population in primary industry to the total employed population.

At the same time, one point should be illustrated, that is, the contribution rate of agricultural scientific and technology progress is the data released from the MOST and provincial MOST; the data of cultivated land area is from the 2008 nation land survey.

\section{Calculation of the development level of national agricultural modernization in 2013}

According to the statistical data in China Statistical Yearbook (2014), China Rural Statistical Yearbook (2014), as calculated, the score of China's agricultural modernization development level is about 66.2 (see Table 1), which is at the development stage of agricultural modernization development.

New progress has been made in the development level of agricultural modernization in China. From the scores of the first grade indices, the sustainable development of agriculture has achieved the goal to the best, the score is $86.4 \%$; followed by the development level in rural areas, reaching $77.7 \%$; the scores of agricultural input and output are $57.9 \%$ and $59.7 \%$, respectively. Due to the total weight 
of agricultural input and output levels has surpassed the total weight, $65 \%$, so the total scores have been affected.

From the second grade indices, the Engel coefficient, the per capita net income of farmers and forest coverage rate have done the best in the realization of target value, the scores are $94 \%, 93 \%$ and $86 \%$ respectively; other indices whose scores are over $50 \%$ in the realization of target value are agricultural science and technology contribution ratio, labor education level, land productivity, agricultural labor force employment rate, effective irrigation rate and labor productivity, they have reached $79 \%, 76 \%, 73 \%, 64 \%, 55 \%$ and $53 \%$ of the target value respectively; some haven't reached the half percent of the target value, they are the total power of the unit cultivated land, per capita capital investment in agriculture, agricultural GDP per capita, the scores are 43\%, 39\% and 35\% respectively.

Table 1 The development level of China's agricultural modernization in 2013

\begin{tabular}{|c|c|c|c|c|c|c|c|}
\hline $\begin{array}{l}\text { First-grade } \\
\text { indices }\end{array}$ & $\begin{array}{l}\text { Second-grade } \\
\text { indices }\end{array}$ & Unit & Weight & $\begin{array}{l}\text { Target } \\
\text { value }\end{array}$ & $\begin{array}{c}\text { The } \\
\text { value of } \\
2013\end{array}$ & $\begin{array}{c}\text { The } \\
\text { realization } \\
\text { of target } \\
\text { value\% }\end{array}$ & $\begin{array}{c}\text { The scores of } \\
\text { the first-grade } \\
\text { indices }\end{array}$ \\
\hline \multirow{5}{*}{$\begin{array}{l}\text { The level of } \\
\text { agricultural } \\
\text { input }\end{array}$} & $\begin{array}{l}\text { Capital } \\
\text { investment in } \\
\text { agriculture per } \\
\text { capita }\end{array}$ & yuan & 6.18 & 7500 & 2899 & 39 & \multirow{5}{*}{18.62} \\
\hline & $\begin{array}{l}\text { Agricultural } \\
\text { science and } \\
\text { technology } \\
\text { contribution ratio }\end{array}$ & $\%$ & 6.28 & 70 & 55.2 & 79 & \\
\hline & $\begin{array}{l}\text { Labor education } \\
\text { level }\end{array}$ & $\%$ & 5.8 & 90 & 68.6 & 76 & \\
\hline & Land productivity & $\mathrm{kw} / \mathrm{hm}^{2}$ & 6.55 & 18 & 7.69 & 43 & \\
\hline & $\begin{array}{l}\text { Effective } \\
\text { irrigation rate }\end{array}$ & $\%$ & 7.36 & 85 & 46.87 & 55 & \\
\hline \multirow{4}{*}{$\begin{array}{l}\text { The level of } \\
\text { agricultural } \\
\text { output }\end{array}$} & $\begin{array}{l}\text { Agricultural GDP } \\
\text { per capita }\end{array}$ & yuan & 11.64 & 25500 & 9046 & 35 & \multirow{4}{*}{19.83} \\
\hline & $\begin{array}{l}\text { Labor } \\
\text { productivity }\end{array}$ & yuan & 6.26 & 40000 & 21305 & 53 & \\
\hline & Land productivity & yuan $/ \mathrm{hm}^{2}$ & 9.05 & 52500 & 38101 & 73 & \\
\hline & $\begin{array}{l}\text { The per capita net } \\
\text { income of farmers }\end{array}$ & yuan & 6.26 & 9600 & 8896 & 93 & \\
\hline \multirow[b]{2}{*}{$\begin{array}{c}\text { The } \\
\text { development } \\
\text { level in rural } \\
\text { areas }\end{array}$} & Engel coefficient & & 11.72 & 40 & 37.7 & 94 & \multirow[b]{2}{*}{19.80} \\
\hline & $\begin{array}{l}\text { Agricultural labor } \\
\text { force employment } \\
\text { rate }\end{array}$ & $\%$ & 13.75 & 20 & 31.4 & 64 & \\
\hline $\begin{array}{c}\text { Agricultural } \\
\text { Sustainable } \\
\text { Development }\end{array}$ & $\begin{array}{l}\text { Forest coverage } \\
\text { rate }\end{array}$ & $\%$ & 9.15 & 25 & 21.6 & 86 & 7.91 \\
\hline Total & & & 100 & & & & 66.16 \\
\hline
\end{tabular}

\section{Comparison of development level of agricultural modernization in China and its provinces in recent five years}

According the the China Rural Statistical Yearbook (2014) and provincial statistical yearbook data in 2014, as calculated, compared with 2008, the development level of agricultural modernization in 
2013, its growth rate has reached about 48\%, with an average annual increase of $8.21 \%$, which indicates that the development level of agricultural modernization has entered the advanced stage from the initial stage. At present, thirty-one provinces, autonomous regions, municipalities have all crossed the initial stage of agricultural modernization, the number that is in the mature stage and in the development level is nine and twenty-two respectively. (See Table 2)

Table 2 Comparison of development level of agricultural modernization in China and its provinces in 2013 and 2008.

\begin{tabular}{|c|c|c|c|c|c|c|}
\hline & $\begin{array}{c}\text { Score of } \\
2013 \\
\end{array}$ & $\begin{array}{l}\text { The stage } \\
\text { of } 2013\end{array}$ & $\begin{array}{c}\text { Score of } \\
2008 \\
\end{array}$ & $\begin{array}{l}\text { The stage } \\
\text { of } 2008\end{array}$ & $\begin{array}{c}\text { Growth } \\
\%\end{array}$ & $\begin{array}{c}\text { Annual } \\
\text { increase }\end{array}$ \\
\hline China & 66.2 & developme] & 44.6 & developmer & 48.36 & 8.21 \\
\hline Beijing & 134.3 & mature & 73.7 & developmer & 82.25 & 12.75 \\
\hline Tianjin & 99.1 & mature & 59.5 & developmer & 66.52 & 10.74 \\
\hline Hebei & 73.9 & developme] & 52.9 & developmer & 39.70 & 6.92 \\
\hline Shanxi & 53.9 & developme] & 37.1 & initial & 45.20 & 7.74 \\
\hline Neimengg & 62.8 & developme] & 43.7 & developmer & 43.60 & 7.51 \\
\hline Liaoning & 79.6 & developme] & 53.8 & developmer & 47.90 & 8.14 \\
\hline Jilin & 69.3 & developme] & 48.0 & developmer & 44.29 & 7.61 \\
\hline $\begin{array}{c}\text { Heilongji } \\
\text { ang }\end{array}$ & 77.8 & developme] & 46.9 & developmer & 65.86 & 10.65 \\
\hline Shanghai & 135.0 & mature & 69.6 & developmer & 93.94 & 14.17 \\
\hline Jiangsu & 83.3 & mature & 58.8 & developmer & 41.68 & 7.22 \\
\hline Zhejiang & 106.5 & mature & 67.1 & developmer & 58.71 & 9.68 \\
\hline Anhui & 68.3 & developme] & 43.3 & developmer & 57.65 & 9.53 \\
\hline Fujian & 104.9 & mature & 62.8 & developmer & 66.98 & 10.80 \\
\hline Jiangxi & 79.8 & developme] & 50.3 & developmer & 58.73 & 9.68 \\
\hline Shangdon & 75.4 & developme] & 54.8 & developmer & 37.54 & 6.58 \\
\hline Hebei & 68.2 & developme] & 48.7 & developmer & 40.06 & 6.97 \\
\hline Hubei & 76.1 & developme] & 47.6 & developmer & 59.77 & 9.82 \\
\hline Hunan & 83.7 & mature & 49.5 & developmer & 69.05 & 11.07 \\
\hline Guangdon & 93.1 & mature & 57.0 & developmer & 63.35 & 10.31 \\
\hline Guangxi & 73.4 & developme] & 42.6 & developmer & 72.34 & 11.50 \\
\hline Hainan & 86.4 & mature & - & - & - & - \\
\hline Chongqin & 69.5 & developme] & - & 一 & - & - \\
\hline Sichuan & 70.4 & developme] & 42.4 & developmer & 65.97 & 10.66 \\
\hline Guizhou & 53.2 & developme] & 31.5 & initial & 68.90 & 11.05 \\
\hline Yunnan & 63.6 & developme] & 39.0 & initial & 62.95 & 10.26 \\
\hline Xizang & 51.9 & developme] & 33.9 & initial & 53.22 & 8.91 \\
\hline Shanxi & 66.4 & developme] & 40.1 & developmer & 65.68 & 10.63 \\
\hline Gansu & 45.9 & developme] & 32.6 & initial & 40.69 & 7.07 \\
\hline Qinghai & 45.8 & developme] & 35.4 & initial & 29.47 & 5.30 \\
\hline Ningxia & 51.5 & developme] & 37.2 & initial & 38.39 & 6.71 \\
\hline Xinjiang & 65.7 & developme] & 41.2 & advanced & 59.42 & 9.78 \\
\hline
\end{tabular}

Note: Datas of Hainan and Chongqing in 2008 are absent.

The development level of agricultural modernization in most provinces is higher than the national average level. There are twenty-two provinces score higher than national average level. From the growth rate, eighteen provinces whose average annual growth rate exceeded the national average level, they are Shanghai, Beijing, Guangxi, Hunan, Guizhou, Fujian, Tianjin, Sichuan, Heilongjiang, Shaanxi, Guangdong, Yunnan, Hubei, Xinjiang, Jiangxi, Zhejiang, Anhui, Tibet, including eastern developed provinces, such as Shanghai, Beijing, Midwest underdeveloped provinces, such as Hubei, Tibet. 
Many provinces have achieved the leap of agricultural modernization. For five years of efforts, eight provinces have entered into the mature stage from the development stage, according to the scores, they are Shanghai, Beijing, Zhejiang, Fujian, Tianjin, Guangdong, Hunan, Jiangsu; seven provinces have entered the development stage from the initial stage, they are Yunnan, Guizhou, Shanxi, Tibet, Ningxia, Gansu, Qinghai.

The province with large population of agricultural industry can reflect the development level of agricultural modernization more. There are six provinces whose scores are over 90 , including three municipalities and two economically developed provinces, the total number of agricultural population is only 12.93 million, accounting for about $5.3 \%$ of the population engaged in agriculture. Compared with this, there are five large agriculture province whose agricultural employment population have exceeded 15 million, they are Henan, Shandong, Sichuan, Hunan, Hubei, the total number of agricultural population is 99.21 million, accounting for about $41 \%$ of the population engaged in agriculture, the scores are 68.2 75.4, 70.4, 83.7 and 76.1, respectively, which can relatively reflect the basic situation of the development level of agricultural modernization.

Western regions, especially in the northwest region, the development level of agricultural modernization is limited. There are five provinces had the lowest scores, they are Guizhou, Tibet, Ningxia, Gansu and Qinghai, all of them located in the west and concentrated in the northwest region.

\section{Conclusion}

From the calculation of the development level of agricultural modernization of national and thirty-one provinces in 2013, compared with that in 2008, the following conclusions are drawn. For five years of efforts, the development level of agricultural modernization in 2013 have entered into the development stage from the initial stage. In the future, it is still an important direction to further advance the construction of modern agriculture, which is to increase the investment level of agriculture and raise the output level of agriculture. Compared with five years ago, fifteen provinces have achieved the stage leap of the development level of agricultural modernization, among them, eight provinces have entered the mature stage from the development stage, seven provinces have entered the development stage from the initial stage. The pace of agricultural modernization in some western regions is slower than the national average, so it is the key area for the government to support the development of agricultural modernization in the future.

\section{Acknowledgements}

Project supported by the Research Foundation from XJAU ( Grant No. XJAU201203); The Xinjiang Uygur Autonomous Region social science planning fund ( Grant No. 14CJY029).

\section{References}

[1] L.Xin, H.P Jiang.(2010) Setting up Evaluation Index System and Calculation Development Level of China Agricultural Modernization, Research of Agricultural Modernization, Vol.31 No.6, pp 646-650. (in Chinese)

[2] H.P Jiang, D.LHuang and L.Hao.(2005) Quantitative evaluation of level of agricultural modernization in China, Issues in Agricultural Economy (S1), pp 52-60,69. (in Chinese)

[3] S.Y.Zhang, X.M.Xia.(2012) Building of agricultural modernization evaluation index system research, The World of Survey and Research,2012-07, pp41-47. (in Chinese)

[4] Q.Shen, Z.J.Hu.(2012)China's agricultural modernization evaluation index system of optimization model-based on clustering and factor analysis, Agricultural Economy, 2015-5, pp3-5. (in Chinese)

[5] H.P Jiang, Q.F.Cui.(2009) Basic implementation of China agricultural modernization evaluation index system of construction and development level of prediction, China Agricultural Technical 
and Economic Research Conference 2009:Technological innovation and modern agricultural development, 2009-09-25, Shenyang, China. (in Chinese) 